\title{
DYNAMIC BEHAVIOUR MAINLY ON PERFORMANCES, ENVIRONMENTAL, SAFETY AND HEALTH BENEFITS OF EUROPEAN HIGH- SPEED TRAINS (MADRID- BARCELONA HIGH- SPEED LINE)
}

\author{
Harish Chandra Maganti \\ Railway Engineer \\ Herzog Rail-Road, United States
}

\author{
Yatish Manju \\ Railway System Engineer \\ Alstom Transport, India
}

\author{
Naga Sai Dilip Kumar Akula \\ Railway Engineer \\ IKOS Consulting, Italy
}

\begin{abstract}
The main aim of this project is to study the Dynamic Behavior mainly focused on Environmental, Safety and Health benefits of different High-Speed Trains which are ETR500, ETR1000, ICE 3, Talgo 350, and TGVThalys with respect to their performance in the HighSpeed line of Madrid - Barcelona which has a speed limit of $300 \mathrm{~km} / \mathrm{hr}$. The main input parameters which are taken into consideration are Mass, Line Speed, Distance, Tractive Effort, Time, Speed, Energy Consumption, etc., Ratios of Mass/Passengers, Energy Consumption/Wheel, Etc. From this comparison, we get to know the performances of different type of high-speed trains in Madrid - Barcelona high-speed line and we can suggest the best one considering all Railway System factors considering all these factors.
\end{abstract}

Railway Systems provide substantial benefits for the Energy-Consuming to the Environment. By using electrical Energy sources and more efficient mobility, Railway Transport can lower energy use and reduce $\mathrm{CO2}$ and Pollutant Emissions.

Keywords - Performances, Environmental, Safety and Health Benefits, Europe High Speed Trains, Madrid, Barcelona, ETR1000, ETR500, Talgo350, ICE3, TGVThalys, Hydrail, Characteristics, Energy Consumption etc;

\section{INTRODUCTION}

Madrid Barcelona Line: It is one of the major high-speed lines in Spain with a total length of $620.9 \mathrm{~km}$ (386 miles) with Standard Gauge $(1435 \mathrm{~mm})$, inaugurated on 20th February 2008 and designed for speeds up to $350 \mathrm{~km} / \mathrm{hr}$ (217 mph). As of 2012, seventeen trains run every day from 6 am to 9 pm, covering the distance between the two cities in just 2 hours 30 minutes for direct trains, and in 3 hours and 10 minutes with stops at intermediate stations with a current speed limit of 300 $\mathrm{km} / \mathrm{hr}$. Level 2 of ETCS/ERTMS signaling systems have been installed to manage traffic along the route and safety. The electric supply system is $25 \mathrm{kV} 50 \mathrm{~Hz}$. Max gradient of the line is $+25.00(1 / 1000)$. This line has diverted $63 \%$ traffic from the air traffic and thus increasing the passenger flow in the trains. The Madrid - Barcelona line of Railway System is more Reliable, Safe, Maintenance Efficient, and Eco-Friendly. In the Table 1, the Major Stations in the line, the Distances, and the speed limits in between them are shown and the railway track map in Figure 1.

\begin{tabular}{|l|l|l|}
\hline Station Name & Distance in $\mathrm{km}$ & $\begin{array}{l}\text { Speed Limit in } \\
\mathrm{km} / \mathrm{h}\end{array}$ \\
\hline Madrid Atocha & 0 & 30 \\
\hline Guadalajara - Yebes & 64.4 & 300 \\
\hline Calatayud & 221.1 & 300 \\
\hline Zaragoza - Delicias & 306.7 & 300 \\
\hline $\begin{array}{l}\text { Lleida Pirineus } \\
\text { Geltokia }\end{array}$ & 442.1 & 300 \\
\hline Camp de Tarragona & 520.9 & 300 \\
\hline Barcelona Sants & 620.9 & 30 \\
\hline
\end{tabular}

Table 1 : Different speed limits in the line

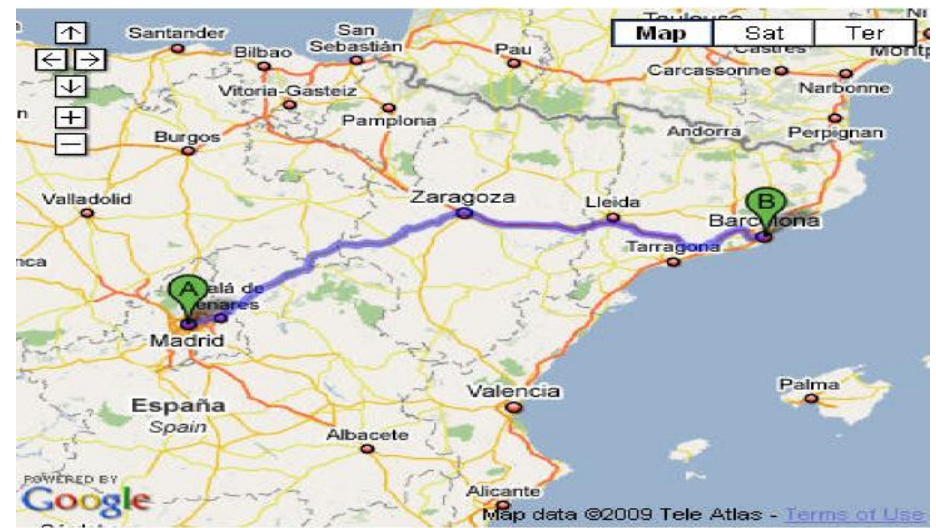


Figure 1: Railway line of Madrid Atocha to Barcelona Sants

As shown in Figure 2, the relation between Gradient and Distance with the actual speed limit of $300 \mathrm{~km} / \mathrm{h}$ between the two stations along with the maximum gradient of the line is $+25.00(1 / 1000)$ with total distance is plotted.

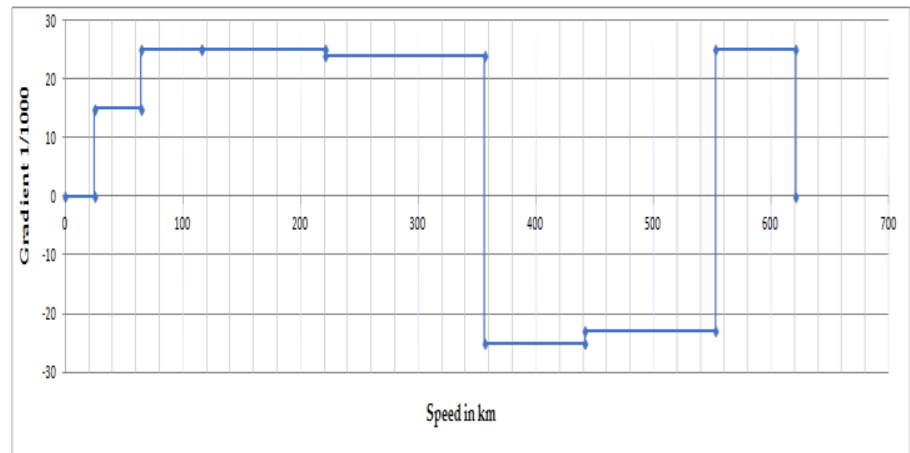

Figure 2 : Gradient level along the line

\section{DEFINITION OF TECHNICAL TOPIC AND ASSESSMENT ANALYSIS}

\section{A. Definition of Technical Topic}

High-Speed Trains are the future in the Railway Transport of Passengers which save travel time, decrease the carbon footprint compared to air transport and are easily accessible being connected to the city center. High-Speed Rail is a mode of Transport that operates faster than regular traffic, with specialized rolling stock and dedicated tracks with higher safety systems and dedicated traffic corridors where many Europe, Asia, United States of America, China \& Japan etc. Countries are developing dedicated high-speed corridors connecting to major cities. Research is being still carried out to date to increase the speed, efficiency keeping in mind safety, signaling systems and to reduce carbon footprint. New technologies like hyper loop may take the future transportation system further.

In our paper we would be discussing the dynamic factors Mass, Line Speed, Distance, Tractive Effort, Time, Speed, Energy Consumption, etc.

Factors calculated due to these ratios are Ratio of Mass/Passengers, Energy Consumption/Wheel etc; \& suggesting a best suitable rolling stock in the line considering all this factors.
B. Train Formation: High-Speed Train formations are classified into two majors is:

ETR 500
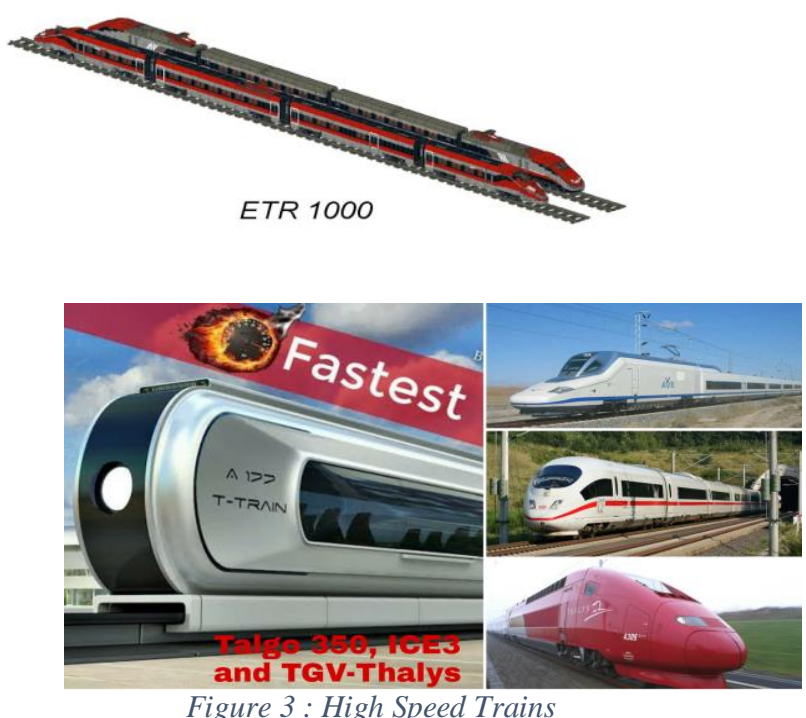

Distributed Power: The practice allows locomotives to be placed anywhere within the length of a train when standard multiple unit operation is impossible or impractical.

Concentrated Power: With one or two end power heads the power is supplied to the train.

C. Assessment Analysis: The basic specifications of the rolling stock used as follows: 
Published Online April 2021 in IJEAST (http://www.ijeast.com)

\section{Characteristics of High-Speed Trains are ETR500,} ETR1000, ICE 3, Talgo 350 \& TGV-Thalys

\begin{tabular}{|c|c|c|c|c|c|}
\hline $\begin{array}{l}\text { Train set } \\
\text { Name }\end{array}$ & TALGO 350 & ETR1000 & ETR500 & ICE 3 & \begin{tabular}{|l} 
TGV- \\
THALYS
\end{tabular} \\
\hline Manufacturer & \begin{tabular}{|l|} 
Bombardier \\
and Talgo
\end{tabular} & \begin{tabular}{|l|} 
Ansaldo / \\
Hitachi rail \\
\end{tabular} & \begin{tabular}{|l|}
$\begin{array}{l}\text { Trevi } \\
\text { consortium }\end{array}$ \\
\end{tabular} & Siemens & Alstom \\
\hline \multirow{2}{*}{ Built at } & \multirow{2}{*}{ Spain } & \multirow{2}{*}{ Pistoia } & \multirow{2}{*}{ Italy } & \multirow{2}{*}{$\begin{array}{l}\text { Deutsche } \\
\text { Bahn }\end{array}$} & France \\
\hline & & & & & \\
\hline Country & Spain & Italy & Italy & Germany & France \\
\hline Constructed & 1998-present & 2010-present & 1988-1998 & 2000-present & 1970-present \\
\hline Entered service & 1998-present & 2015 & 1990-present & 2000-present & 1998-present \\
\hline Number built & 25 & 50 & 61 & 50 & 17 \\
\hline \multirow[t]{2}{*}{ Formation } & \multirow{2}{*}{$\begin{array}{l}2 \text { head power } \\
\text { cars and } \\
11 \text { cars }\end{array}$} & 8 cars & \begin{tabular}{|l|}
2 \\
locomotives+ \\
\end{tabular} & \multirow{2}{*}{$\begin{array}{l}8 \text { cars } \\
\text { distributed } \\
\text { power }\end{array}$} & \begin{tabular}{|l|}
10 cars \\
concentrated \\
\end{tabular} \\
\hline & & distributed & 11trailor & & \\
\hline Capacity & 370 seats & 457 seats & 574 seats & 405 seats & 377 seats \\
\hline Operator & Renfe & Trenitalia & Trenitalia & \begin{tabular}{|l} 
Deutsche \\
Bahn
\end{tabular} & SNCF \\
\hline $\begin{array}{l}\text { Car body } \\
\text { construction }\end{array}$ & $\begin{array}{l}\text { Aluminium } \\
\text { alloy }\end{array}$ & $\begin{array}{l}\text { Aluminium } \\
\text { alloy }\end{array}$ & $\begin{array}{l}\text { Aluminium } \\
\text { alloy }\end{array}$ & $\begin{array}{l}\text { Aluminium } \\
\text { alloy }\end{array}$ & \begin{tabular}{|l} 
Aluminium \\
with carbon \\
composite \\
\end{tabular} \\
\hline Train length & $200 \mathrm{~m}$ & $202 \mathrm{~m}$ & $204.6 \mathrm{~m}$ & $200.32 \mathrm{~mm}$ & 200 \\
\hline Width & $2,942 \mathrm{~mm}$ & $2,924 \mathrm{~mm}$ & $3,020 \mathrm{~mm}$ & $2,95 \mathrm{~mm}$ & $2,81 \mathrm{~mm}$ \\
\hline Height & $4,080 \mathrm{~mm}$ & $4,080 \mathrm{~mm}$ & $4,000 \mathrm{~mm}$ & $3,89 \mathrm{~mm}$ & \\
\hline Floor height & $1,240 \mathrm{~mm}$ & $1,240 \mathrm{~mm}$ & & $1,240 \mathrm{~mm}$ & \\
\hline Wheel diameter & & $920 \mathrm{~mm}$ & $1040 \mathrm{~mm}$ & $920 \mathrm{~mm}$ & \\
\hline \multirow{2}{*}{ Maximum speed } & $300 \mathrm{~km} / \mathrm{h}$ & $300 \mathrm{~km} / \mathrm{h}$ & $300 \mathrm{~km} / \mathrm{h}$ & $300 \mathrm{~km} / \mathrm{h}$ & $300 \mathrm{~km} / \mathrm{h}$ \\
\hline & (operating) & (operating) & (operating) & (operating) & (operating) \\
\hline Tail load & 322 ton & 454 ton & 598 ton & 439 ton & 383 ton \\
\hline Head load & 358 & 490 ton & 664ton & 474 ton & 428 ton \\
\hline Axle load & 17 ton & 17 ton & 17 ton & 17 ton & 17 ton \\
\hline \multirow{2}{*}{ Traction system } & \multirow{2}{*}{$\begin{array}{l}\text { Asynchronou } \\
\text { s ac traction } \\
\text { motors }\end{array}$} & $\begin{array}{l}\text { Water cooled } \\
\text { IGBT } \\
\text { converters. }\end{array}$ & \multirow{2}{*}{$\begin{array}{l}\text { Asynchronou } \\
\text { s traction } \\
\text { motors }\end{array}$} & & \\
\hline & & $\begin{array}{l}\text { Asynchronou } \\
\text { s ac traction } \\
\text { motors } \\
\end{array}$ & & & \\
\hline Power output & $4000-4400$ & $9,800 \mathrm{kw}$ & $8800 \mathrm{kw}$ & $8,800 \mathrm{kw}$ & $5,500 \mathrm{kw}$ \\
\hline Tractive effort & $400 \mathrm{kn}$ & $370 \mathrm{kn}$ & $340 \mathrm{kn}$ & $300 \mathrm{kn}$ & $220 \mathrm{kn}$ \\
\hline Acceleration & $1.2 \mathrm{~m} / \mathrm{s} 2$ & $0.7 \mathrm{~m} / \mathrm{s} 2$ & & & \\
\hline Deceleration & & $1.2 \mathrm{~m} / \mathrm{s} 2$ & & & \\
\hline Electric system & $25 \mathrm{kv} 50 \mathrm{hz}$ & $25 \mathrm{kv} 50 \mathrm{hz} \mathrm{ac}$ & $25 \mathrm{kv} 50 \mathrm{hz}$ & $25 \mathrm{kv} 50 \mathrm{hz}$ & $25 \mathrm{kv} 50 \mathrm{hz}$ \\
\hline Current method & Pantograph & Pantograph & Pantograph & Pantograph & Pantograph \\
\hline \multirow{3}{*}{ Braking system } & \begin{tabular}{|l|}
$\begin{array}{l}\text { Regenerative } \\
\text { system }\end{array}$ \\
\end{tabular} & $\begin{array}{l}\begin{array}{l}\text { Regenerative } \\
\text { system }\end{array} \\
\end{array}$ & \multirow{3}{*}{$\begin{array}{l}\text { Pneumatic, } \\
\text { rheostatic }\end{array}$} & \begin{tabular}{|l|}
$\begin{array}{l}\text { Regenerative } \\
\text { system }\end{array}$ \\
\end{tabular} & \multirow{3}{*}{ Pneumatic } \\
\hline & \multirow[t]{2}{*}{ Rheostatic } & $\begin{array}{l}\text { Dynamic } \\
\text { system }\end{array}$ & & Pneumatic & \\
\hline & & \begin{tabular}{|l|}
$\begin{array}{l}\text { Electro } \\
\text { pneumatic }\end{array}$ \\
\end{tabular} & & Rheostatic & \\
\hline Safety system & ETCS & $\begin{array}{l}\text { ERTMS, } \\
\text { ETCS }\end{array}$ & $\begin{array}{l}\text { ERTMS, } \\
\text { ETCS }\end{array}$ & $\begin{array}{l}\text { ERTMS, } \\
\text { ETCS }\end{array}$ & $\begin{array}{l}\text { ERTMS, } \\
\text { ETCS }\end{array}$ \\
\hline Track gauge & $\begin{array}{l}1,435 \mathrm{~mm} \\
\text { (standard) }\end{array}$ & $\begin{array}{l}1,435 \mathrm{~mm} \\
\text { (standard) }\end{array}$ & $\begin{array}{l}1,435 \mathrm{~mm} \\
\text { (standard) }\end{array}$ & $\begin{array}{l}1,435 \mathrm{~mm} \\
\text { (standard) }\end{array}$ & $\begin{array}{l}1,435 \mathrm{~mm} \\
\text { (standard) }\end{array}$ \\
\hline
\end{tabular}

Table 2 : General Specifications of Specified Trains

\section{Performance Analysis of these various Rolling stock in Madrid-Barcelona Line}

Theoretical Methodology for this operation is to know the Performance of Train of various factors to derive Distance, Time, Acceleration, and Energy Consumption of both engine $\&$ wheel of considered factors:

The motion consists of three phases: starting, constant and braking. The commercial speed is obtained as the ratio between the distance travelled and the time employed to follow it.

Acceleration (a) and assumed constant deceleration (d) are Valid for the following formulas.

General equation of motion $=>$ Force: It is relation between mass and acceleration.

$$
F=M a[\mathrm{~N}]
$$

Exact resolution (continuous function) $\Rightarrow$ Time: it is relation between mass and delta speed by Subtracting Traction Force and Resistance force.

$$
d t=\frac{M d v}{T(v)-R(v)}[\mathrm{s}]
$$

Finite elements approximate resolution:

$($ Discrete function $)=\Delta t=$ mass $*$ speed $/$ Traction Force-Resistance force.

$$
\begin{array}{rll}
\Delta t= & \frac{M \Delta v}{T(v m)-R(v m)} & {[\mathrm{s}]} \\
& S a=\frac{(V \max ) 2}{2 * a} & {[\mathrm{~m}]} \\
& t a=\frac{V \max }{a} & {[\mathrm{~s}]} \\
& s f=\frac{V \max 2}{2 * d} & {[\mathrm{~m}]} \\
& t f=\frac{V \max }{d} & {[\mathrm{~s}]}
\end{array}
$$$$
\begin{array}{lll}
\text { Starting Acceleration: } & t a=\frac{V \max }{a} \quad[\mathrm{~m}]
\end{array}
$$$$
\text { Braking Force: } \quad S f=\frac{V \max 2}{2 * d} \quad[\mathrm{~m}]
$$

Force Time:

Commercial speed $(V c)$ It is defined as Distance of origin to destination by Total travelling time of origin to destination.

$$
V c=\frac{L}{t a+t r+t f+t s}[\mathrm{~m} / \mathrm{s}] \text { or }[\mathrm{km} / \mathrm{h}]
$$

Power: It is relation between Tractive Force and Speed.

$$
P=T * V \quad[\mathrm{~kW}] \text { or }[\mathrm{W}]
$$

Energy Engine: It is relation between Power and time.

$$
\text { E engine }=P \text { * } t[\mathrm{~kW}-\mathrm{h}] \text { or }[\mathrm{W}-\mathrm{h}]
$$

Energy Wheel: It is relation between E engine and Efficiency.

$$
\text { E wheel }=\text { E engine } * \eta_{[\mathrm{kW}-\mathrm{h}]} \text { or }[\mathrm{W}-\mathrm{h}]
$$

Ratio: Normal Resistance (ETR 500) = Mass of ETR $500 *$ Resistance (ETR 1000) / mass of ETR 1000.

$$
R(\text { ETR } 500)=\frac{M(E T R 500) * R(\text { ETR } 1000)}{M(E T R 1000)}[\mathrm{N}] \text { or }[\mathrm{kN}]
$$

Resistance with Slope: Actual resistance of train+ ((gradient * weight of train) (included tunnel))

$$
R(\text { Slope })=R+(i * W)[\mathrm{N}] \text { or }[\mathrm{kN}]
$$




\section{E. High-Speed Passenger Train comparison of Talgo 350, ETR1000, ETR 500, ICE 3 \& SNFC TGV-THALYS}

We are comparing with the five different Rolling Stock or Trains; from the following graphs we get to know:

Performance of the rolling stock, Behavior of the rolling stock, Acceleration with respect to Speed, Energy Consumption of the rolling stock.

\section{F. Relation of Speed v/s Distance:}

We are comparing this speed and distance with actual limit, performance, and behavior of Talgo350, ETR1000, ETR500, ICE 3 and TGV-Thalys are performing varies speed with distance frequently as shown where ICE3 reaches top speed fast and in terms of deceleration TGV reaches zero fast as shown in Figure 5.

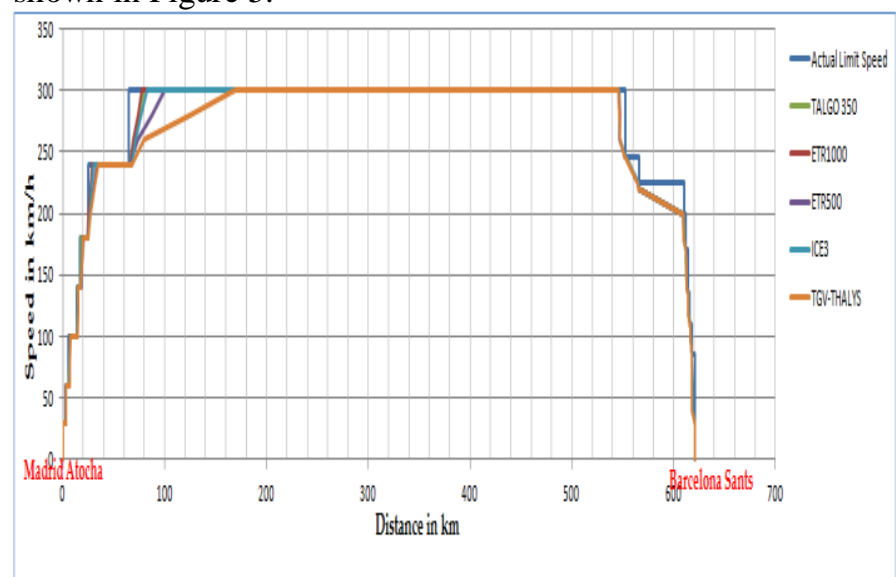

Figure 4: Speed vs. Distance

\section{G. Relation of Speed v/s Time:}

We are comparing the Speed and Time with actual limit; we consider it with Speed limit to reach destination point with a speed limit of $300 \mathrm{~km} / \mathrm{h}$ depicted in Figure 6.

- $\quad$ ETR1000 takes 9179 Seconds, where ETR 500 takes 9180 Seconds and ICE 3 takes 9174 Seconds and is taking the same time to reach destination.

- Talgo 350 takes less time than other Trains to reach destination Barcelona in 9157 Seconds.

- TGV-Thalys Train takes time 9255 Seconds to reach destination Barcelona which is the highest among all.

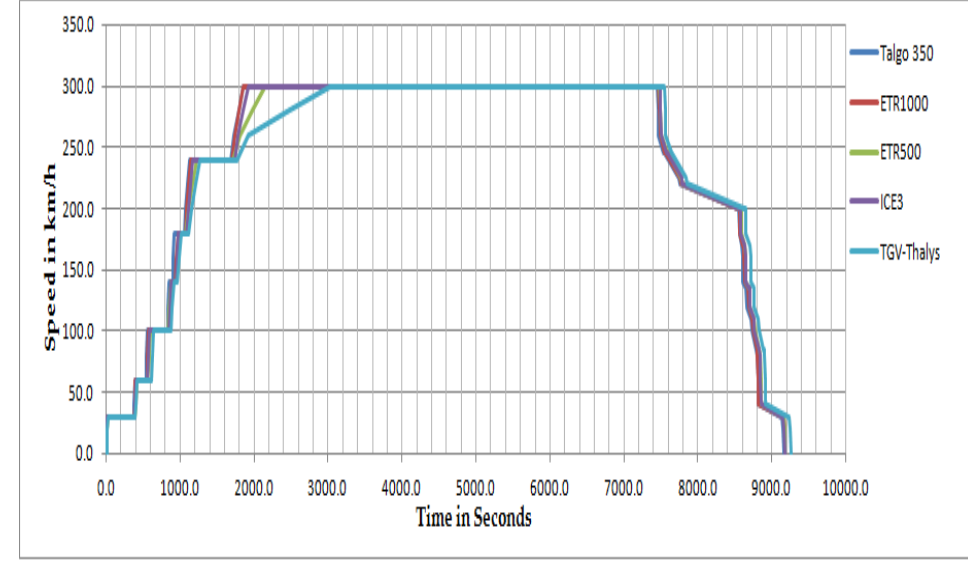

Figure 5: Speed vs. Time

\section{H. Relation of Distance v/s Time:}

We are comparing the Distance and Time with actual limit, to reach destination depicted in Figure 7.

- $\quad$ ETR1000 takes 9179 Seconds, ETR 500 takes 9180 Seconds and ICE 3 takes 9174 Seconds take the same time to cover the distance of $620.9 \mathrm{~km}$.

- Talgo 350 lesser time taken than other Trains and reaches in 9157 Seconds.

- TGV-Thalys Train takes 9255 Seconds to reach destination Barcelona highest among all.

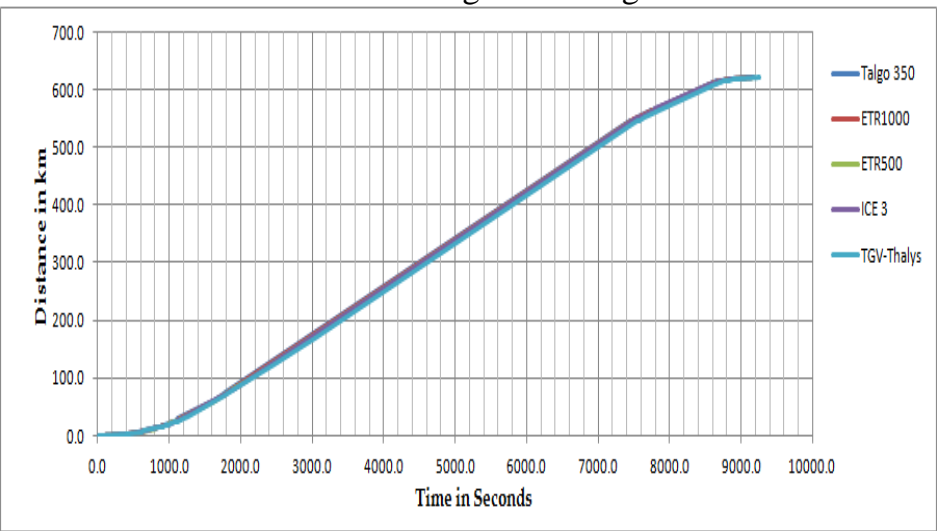

Figure 6: Distance vs. Time

\section{Relation of Energy consumption Wheel v/s Distance:}

From this graph of Energy Consumption of Wheel and Distance with speed limit at $300 \mathrm{~km} / \mathrm{hr}$ from theory of Equation depicted in Figure 8.

Energy input or engine $=$ power $*$ time

$$
\text { E imput }=P * t \quad[\mathrm{~kW}-\mathrm{h}]
$$

In this case when we compare the performance of high-speed passenger trains:

- $\quad$ ETR 500 consumed more energy $13393(\mathrm{~kW}-\mathrm{h})$ than remaining all Trains, because of a greater number of 


\section{International Journal of Engineering Applied Sciences and Technology, 2021 \\ Vol. 5, Issue 12, ISSN No. 2455-2143, Pages 247-253 \\ Published Online April 2021 in IJEAST (http://www.ijeast.com)}

seats/passengers, thus increasing the Energy Consumption.

- Talgo 350 Energy consumed 11314(kW-h), ETR1000 Energy consumed 11489(kW-h) and ICE 3 Energy consumed 11501(kW-h) which consume less Energy than ETR500.

- $\quad$ TGV-Thalys consumed $9876(\mathrm{~kW}-\mathrm{h})$ less energy than all other Trains.

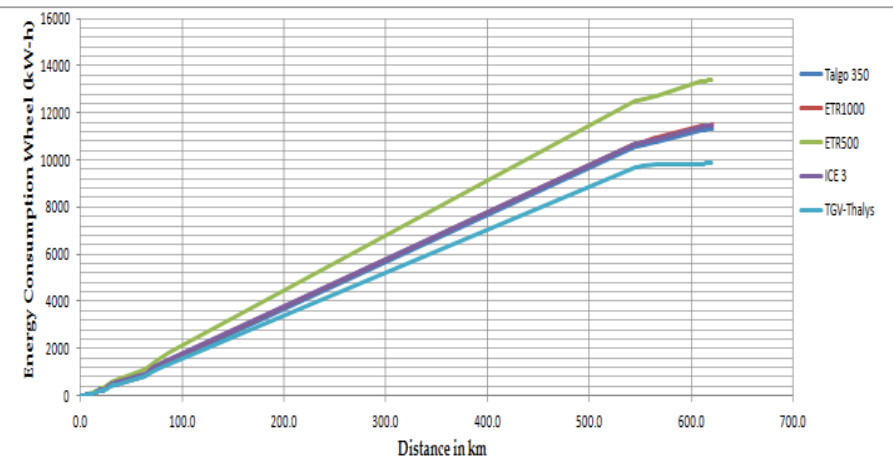

Figure 7: Energy Consumption Wheel vs. Distance

\section{J. Relation of Energy Consumption Engine v/s Distance:}

Assuming,

Efficiency is $90 \%$ and from theory of Equation,

Energy Engine = Energy Wheel/ efficiency

$$
\text { E engine }=E \text { Wheel } / \eta[\mathrm{kW}-\mathrm{h}]
$$

In this case, we would be comparing the performance of these trains in Figure 9.

- ETR 500 consumed more Energy consumed 13393(kW-h) than remaining all Trains, because of a greater number of seats/passengers and increasing the Energy Consumption.

- Talgo 350 Energy consumed 11314(kW-h), ETR1000 Energy consumed 11489(kW-h) and ICE 3 Energy consumed 11501(kW-h) energy.

- $\quad$ TGV-Thalys Energy Consumed energy $9876(\mathrm{~kW}-\mathrm{h})$ less than all other Trains.

As per practical knowledge, Engine consumes more energy than Wheel because Engine feeds the motor which runs the wheels.

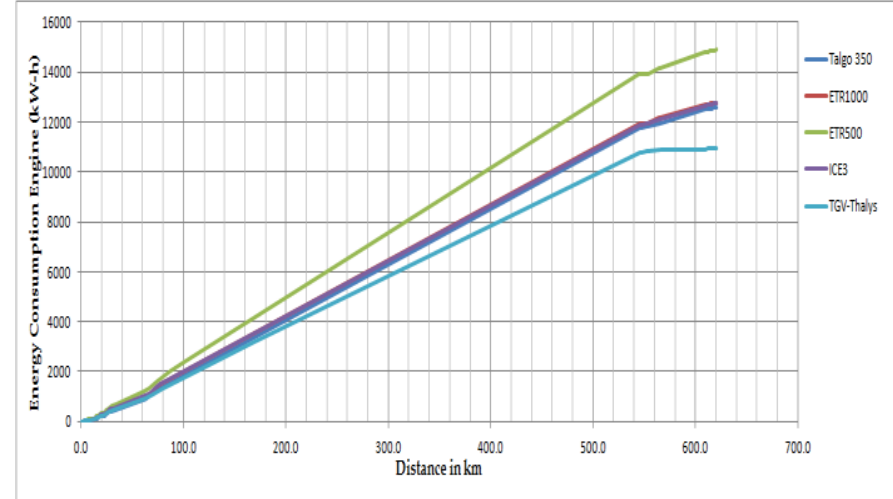

Figure 8 : Energy Consumption Engine vs. Distance

\section{$K$. Focusing on Criteria of Passengers:}

In the below graph Figure 10, we are showing a relation between different Trains to Number of Passengers seating per Train.

ETR500 High-Speed Train: have highest number of seats available in train compared to other Trains.

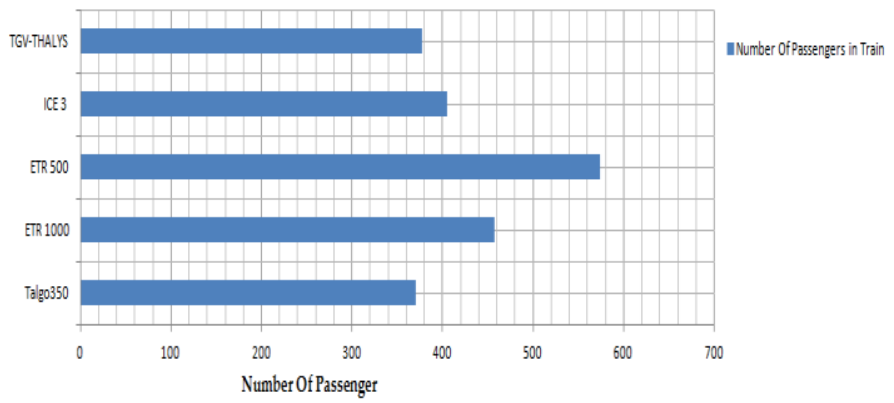

Figure 9: Trains vs. Passenger Seating Capacity

\section{Operating Solutions:}

$>$ If the passengers are less, and then energy will be consumed less

$>$ If the passengers are high, and then energy will be consumed more

From the graph in Figure 11, we can depict energy consumed of each train with respect to different seating arrangements. 


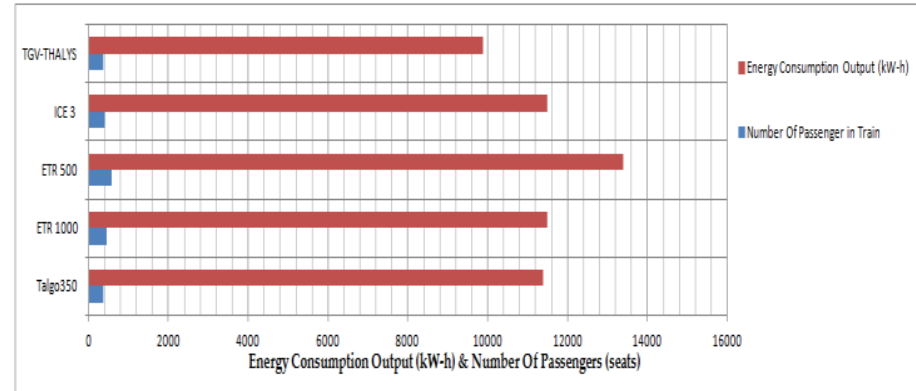

Figure 10: Different seating arrangements and energy consumption with respect to train

From the above graphs, we calculated and found results of different Trains by comparing the following factors as shown in Table 3 and highlighting the best performance ones:

\begin{tabular}{|c|c|c|c|c|c|}
\hline Train Name & $\begin{array}{l}\text { TALGO } \\
350 \\
\end{array}$ & ETR1000 & ETR500 & ICE 3 & TGV-THALYS \\
\hline Railway Line & \multicolumn{5}{|c|}{ Madrid Atocha to Barcelona Sants } \\
\hline Mass (ton) & 358 & 490 & 664 & 474 & 428 \\
\hline Maximum Line Speed $(\mathrm{km} / \mathrm{h})$ & 300 & 300 & 300 & 300 & 300 \\
\hline Distance $(\mathrm{km})$ & 620.9 & 620.9 & 620.9 & 620.9 & 620.9 \\
\hline Cruising Distance $(\mathrm{km})$ & 465.4 & 467.7 & 444.8 & 463 & 376.2 \\
\hline Passengers in Train (Seats) & 370 & 457 & 574 & 405 & 377 \\
\hline Tractive Effort (kN) & 400 & 370 & 350 & 287 & 220 \\
\hline Time (Seconds) & 9157 & 9179 & 9180 & 9174 & 9255 \\
\hline Commercial Speed $(\mathrm{km} / \mathrm{h})$ & 244 & 244 & 243 & 244 & 242 \\
\hline Energy Consumption Wheel (kW-h) & 11314 & 11489 & 13393 & 11501 & 9876 \\
\hline Energy Consumption Engine $(\mathrm{kW}-\mathrm{h})$ & 12571 & 12766 & 14881 & 12779 & 10973 \\
\hline Energy Consumption Wheel $(\mathrm{kW}-\mathrm{h})$ Cruising & 9321 & 9393 & 10379 & 9241 & 6829 \\
\hline Energy Consumption Engine (kW-h) Cruising & 10357 & 10437 & 11532 & 10268 & 7588 \\
\hline Power Maximum Stored $(\mathrm{kW})$ & 8000 & 9800 & 8800 & 8800 & 8800 \\
\hline Power Used $(\mathrm{kW})$ Cruising & 6008 & 6025 & 7000 & 5988 & 5446 \\
\hline Ratio $=($ MASS $/$ Passengers $)$ & 0.97 & 0.99 & 0.89 & 1.08 & 1.02 \\
\hline Ratio $=($ Power Used (Cruising)/MASS) $)$ & 17 & 13 & 14 & 14 & 14 \\
\hline Ratio $=($ Power Used $($ Cruising $) /$ Passengers $))$ & 16 & 13 & 12 & 15 & 14 \\
\hline $\begin{array}{l}\text { Ratio= (Energy Consumption } \\
\text { Wheel/Distance) }\end{array}$ & 18 & 19 & 22 & 19 & 16 \\
\hline $\begin{array}{l}\text { Ratio }=(\text { Energy Consumption Wheel } \\
(\text { CRUISING)/Distance) }\end{array}$ & 20 & 20 & 23 & 20 & 18 \\
\hline $\begin{array}{l}\text { Ratio }=(\text { Energy Consumption Engine } \\
\text { /Distance) }\end{array}$ & 20 & 21 & 24 & 21 & 18 \\
\hline $\begin{array}{l}\text { Ratio }=(\text { Energy Consumption Engine } \\
(\text { Cruising } / \text { Distance) }\end{array}$ & 22 & 22 & 26 & 22 & 20 \\
\hline $\begin{array}{l}\text { Ratio }=\text { (Energy Consumption } \\
\text { Wheel/Distance*Passengers) }\end{array}$ & 0.05 & 0.04 & 0.04 & 0.05 & 0.04 \\
\hline $\begin{array}{l}\text { Ratio }=\text { (Energy Consumption Wheel } \\
\left(\text { CRUISING)/Distance }{ }^{*} \text { Passengers }\right)\end{array}$ & 0.04 & 0.04 & 0.05 & 0.04 & 0.03 \\
\hline $\begin{array}{l}\text { Ratio }=\text { (Energy Consumption Engine } \\
\text { /Distance*Passengers) }\end{array}$ & 0.05 & 0.04 & 0.04 & 0.05 & 0.05 \\
\hline $\begin{array}{l}\text { Ratio }=(\text { Energy Consumption Engine } \\
(\text { CRUISING)/Distance* Passengers) }\end{array}$ & 0.05 & 0.05 & 0.05 & 0.04 & 0.03 \\
\hline $\begin{array}{l}\text { Ratio }=(\text { Energy Consumption } \\
\text { Wheel/Passengers })\end{array}$ & 31 & 25 & 23 & 28 & 26 \\
\hline $\begin{array}{l}\text { Ratio }=(\text { Energy Consumption Wheel } \\
(\text { CRUISING)/Passengers) }\end{array}$ & 25 & 21 & 18 & 23 & 18 \\
\hline $\begin{array}{l}\text { Ratio = (Energy Consumption } \\
\text { Engine/Passengers) }\end{array}$ & 34 & 28 & 26 & 32 & 29 \\
\hline $\begin{array}{l}\text { Ratio }=(\text { Energy Consumption Engine } \\
(\text { CRUSING)/Passengers })\end{array}$ & 28 & 23 & 20 & 25 & 20 \\
\hline
\end{tabular}

Table 3: Table showing different ratios

From Table 3, we can conclude by saying that in the various factors that were taken into consideration TGV-Thalys can be best train in this route as the best one with Talgo 350 at the least preferable one.

\section{FUTURE ASSESMENT}

\section{A. Future Assessment of High-Speed Railway Technology Development}

Technologies that are used for Railway System are based on Technical Specifications of Interoperability \& CENELEC
Standards which are used worldwide, respecting also UIC standards. System and Products are approached through FailSafe Condition and Redundancy using for Safety Purpose.

New technologies are continuously tested and implemented reduce Hazards are Miscommunications between Train to Track and Train to Train, Braking, Derailment, Collision, and Climatic Conditions.

They are also being used in Railway Infrastructure, Rolling Stock, Signaling, and Tele-Communication to make better Mobility for Timesaving, Safe, Comfort Level of Service, and Cost. They can be spoken as

1. Railway Infrastructure Systems: Future Network Development for High-Speed Line, Track Gauge, Electrification and Constructing Tunnels.

2. Rolling Stock Systems: Electric Trains are Distributed Power, Concentrated Power \& Two locomotive, and trailers. Safety Systems are Onboard Equipment, Emergency Braking, and Speed Controlling.

3. Signaling Systems: Future Signaling Safety Systems are using for Traffic Control Track Side Equipment's Technologies are ERTMS (Level2 \& Level3) \& ETCS are used globally.

4. Future Tele-Communication or Transformation Information Systems: Safety Systems are IoT (Internet of Things), Artificial Intelligence, Data Analytics for Interfacing Commands.

\section{B. Future Development on Hydrogen Power Trains to better for Environmental, Safety, Health, and Sustainability benefits}

Hydrail: Also known as Hydrogen Power Trains these are the future in regional transport of passengers and surely can also be used in high-speed lines. It is powered by Hydrogen fuel battery hybrid propulsion technology, Hydrail is being proven worldwide as an innovative electrification technology that eliminates emissions at the point of use (railway yards, terminals, etc.) aside from pure water. In addition to zeroemissions, Hydrail power runs silently, a major improvement on the High-Speed Rails is Noise and Vibration from their ETR500, ETR1000, Talgo 350, ICE 3 and TGV-Thalys electric counterparts. Several proofs-of-concept and in-service Hydrail Systems have been demonstrated over the last 20 years, and it is gaining Traction or Braking Power as an Attractive and Economically Reliable technology, especially for low-power, short-haul applications in the rail industry. To achieve emission reduction policy goals, aiming to improve air quality while reducing greenhouse gases to lower the impact of climate change.

\section{IV.CONCLUSION}

We can conclude my saying that High-Speed rail is one of the best alternatives to other modes of transport like Road, Air. Railways also aid in conserving the environment as they 


\section{International Journal of Engineering Applied Sciences and Technology, 2021 \\ Vol. 5, Issue 12, ISSN No. 2455-2143, Pages 247-253 \\ Published Online April 2021 in IJEAST (http://www.ijeast.com)}

produce less carbon emissions and in terms of safety from the previous years, 95\% trains run systematically, and the remaining $5 \%$ the chance of failures are due to Technical errors, Human Behaviors and Climatic Conditions.

From the different ratios we have calculated, one factor we may find one train performing better i.e., Energy consumption output wheel in cruising there we find TGV-Thalys with the minimum value, where if we consider another factor train to be better i.e. In Ratio Mass/Passengers we find ETR500 to be the last one and it continues. We can conclude by saying that each train has its own characterizes, but TGV-Thalys is the best suitable train considering all factors Madrid-Barcelona HighSpeed Line from our calculations.

\section{REFERENCE}

[1] https://en.wikipedia.org/wiki/High-speed_rail.

[2] https://en.wikipedia.org/wiki/Madrid\%E2\%80\%93Barcel ona_high-speed_rail_line.

[3] https://www.globalrailwayreview.com/news/66620/barcel ona-madrid-85-million-passengers/.

[4] https://www.bombardier.com/en/transportation/productsservices/bogies.html -Using this catalogue for weight analysis.

[5] https://www.mobility.siemens.com/mobility/global/sitecol lectiondocuments/en/rail-solutions/components-andsystems/bogies-catalog-en.pdf - Using this catalogue for weight analysis.

[6] https://en.wikipedia.org/wiki/AVE_Class_102 -Talgo 350 High Speed Passenger Train.

[7] https://en.wikipedia.org/wiki/Frecciarossa_1000 ETR1000 High Speed Passenger Train.

[8] https://it.wikipedia.org/wiki/Treno_FS_ETR.500 ETR500 High Speed Passenger Train.

[9] https://en.wikipedia.org/wiki/Siemens_Velaro - ICE 3 Velaro E High Speed Train.

[10] https://en.wikipedia.org/wiki/SNCF_TGV_Thalys_PBKA - SNCF TGV-Thalys High Speed Passenger Train.

[11] https://hsr.ca.gov/docs/programs/eir_memos/Proj_Guideli nes_TM3_2_2R01.pdf -Parsons Brinckerhoff

[12] Antoine DEFOSSEZ, Denis BIASIN (IU-PRM_TSI), 2012.

[13] https://assets.new.siemens.com/siemens/assets/api/uuid:f8 bb84ab18e118497745eb3d7221e0ce7c2d1b9b/mo-velarobrochure-2016-en.pdf ICE3 High-Speed Train

[14] http://www.railway-research.org/IMG/pdf/117.pdf Giampaolo Mancini, Donato Carillo, Paolo Presciani, Pierandrea Cossu ETR500 High- Speed Train.
[15] Bianchi C., Casini C., Roberti R.: "La Carrozza Laboratorio del treno ETR X 500". La Tecnica Professionale no.8, Rome, Italy, August 1989.

[16] Casini C.: "La campagna sperimentale ad Alta velocità: obbiettivi, metodologia organizzazione e risorse impiegate". Ingegneria ferroviaria no. 6, Rome, Italy, June 1993.

[17] https://www.transportesenegocios.pt/seminarios/anteriore s/2006/TransporteFerroviario/Luis_Coimbra.pdf.

[18] http://www.cifi.it/UplDocumenti/AV_Freccia1000/BOM BARDIER\%20ETR1000.pdf -Diego Canetta ETR1000 High-Speed Train.

[19] https://www.talgo.com/en/talgo-350. 